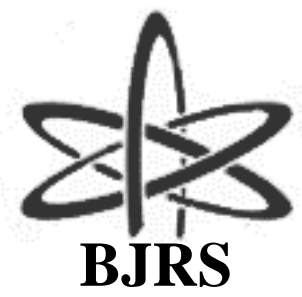

\author{
BRAZILIAN JOURNAL \\ $\mathrm{OF}$ \\ RADIATION SCIENCES \\ 09-01A (2021) 01-15
}

\title{
Analysis of South America coins of the XIX and XX centuries by XRF technique
}

\author{
Nardes $^{a}$ R.C., Sanches ${ }^{a}$ F.A.C.R.A., Santos ${ }^{a}$ R.S., Geraldes ${ }^{b}$ M. C., Assis ${ }^{c}$ J.T., \\ Anjos $^{\mathrm{a}}$ M.J. \\ ${ }^{a}$ Universidade do Estado do Rio de Janeiro, Instituto de Física, 20550-900, Rio de Janeiro, RJ, Brasil \\ rc.nardes@gmail.com; francissanches@gmail.com; ramonziosp@yahoo.com.br; \\ marcelin@uerj.br \\ ${ }^{b}$ Universidade do Estado do Rio de Janeiro, Faculdade de Geologia, 20550-900, Rio de Janeiro, RJ, Brasil \\ mauro.geraldes@gmail.com \\ ${ }^{c}$ Universidade do Estado do Rio de Janeiro, Instituto Politécnico, 28625-570 Nova Friburgo, RJ, Brasil
}

joaquim.iprj@gmail.com

\begin{abstract}
In this work, the elemental composition of 21 coins from nineteenth and twenty centuries of South America was analyzed using X-Ray Fluorescence (XRF) technique to determine the type of alloy used for manufacturing coins and to check for possible fakes. Different numismatic catalogs were used as reference material to compare the compositions. In this collection, twenty coins were minted in Bolivia from 1876 to 1980, and one coin was minted in Peru in 1956. The XRF measurements were performed using ARTAX 200 system (Bruker AXS Inc., Madison, WI, USA), which consists of an X-ray tube with Mo anode and a Silicon Drift Detector. The analyses were performed with a voltage and current of $40 \mathrm{kV}$ and $600 \mu \mathrm{A}$, respectively, and an acquisition time of $100 \mathrm{~s}$. It was possible to identify 4 different alloys by means of the elemental composition of each coin. The major elements found were $\mathrm{Fe}, \mathrm{Cu}, \mathrm{Ni}, \mathrm{Zn}$ and $\mathrm{Sn}$. All coins were identical in appearance to their cataloged version. In addition, the results obtained from 20 coins indicate that the alloys of these coins are in accordance with the literature. However, the result obtained for the alloy of the Bolivian coin minted in 1942 does not match its cataloged version, which may be indicative of fake. The results demonstrate that the XRF technique is an efficient method for identifying the metallic composition of coins, besides to assisting in the authentication of artifacts of historical interest.
\end{abstract}

Keywords: XRF, Archaeometry, XX and XIX century coins. 


\section{INTRODUCTION}

Coins analysis is a subject that has been studied by many researchers since they are considered a living representation of the history of a people. The determination of the chemical composition of ancient and modern coins may offer valuable information to archaeologists, historians, numismatics, and coin dealers, mainly regarding their manufacturing technology and authenticity, source of raw material, the geographical distribution, and period of their minted $[1,2]$.

However, studying numismatics or collecting coins is not restricted only to historical interest. Buying, selling and trading coins, especially old and rare ones, can be an expensive investment, so the application of non-destructive analytical techniques in the Archaeometry study is important, mainly because you can identify fake pieces [3]. Data from virtually all types of coins, most of which are photographed, with the mint year and other information, can be found in the online numismatics catalogs. Coin catalogs are essential when dealing with ancient or foreign coins and provide a comprehensive guide for both beginner and advanced collectors [4, 5].

$\mathrm{X}$-ray fluorescence (XRF) has been widely used as a fast and efficient method of helping to authenticate art and archaeological artifacts. The XRF technique is essentially non-destructive and provides with good accuracy the elemental composition of the constituent materials [6, 7].

Twenty-one coins from the nineteenth and twenty centuries of South America were analyzed using XRF technique. The collection of 21 coins analyzed is a very representative sampling of two South American countries (Peru and Bolivia). The Peruvian coin "Sol de Oro" used from 1943 to 1965 and removed from circulation after two major events that affected the country economically [8]. Moreover, this collection includes twenty coins that tell the story of more than 1 century (1876 - 1980) of mintage occurred in Bolivia and depict the evolution of the country's historical and economic context over this period, showing the different alloys used. The aim of this work was to determine the elemental composition of 21 coins using X-Ray Fluorescence (XRF) technique to determine the type of alloy used for the coins and to check for possible fakes by comparing the results obtained with the data compiled in the literature and numismatic catalogs. 


\section{MATERIALS AND METHODS}

\subsection{Coin Samples}

This study comprised twenty-one coins from the 19th and 20th centuries (1 Peruvian and 20 Bolivians) belonging to a private collection. The coins were classified, separated and named by letters from A to $\mathrm{U}$ before XRF analysis. Tables 1 to 3 show the coins classified according to the mint year, country, face value, size including diameter (Ø), thickness (Thkns), and the type of alloy. In addition, tables 1 to 3 also show the description of the analyzed coins obtained experimentally and their description available in the literature $[4,5]$. Besides that, all coins have been identified according to their shapes, obverse, and reverse, where it is possible to identify the color resulting from their alloy. Obverse and reverse refer to the two flat faces of coins. The obverse of a coin is usually called "heads" because it often represents the head of a prominent person and the reverse of a coin is the "tails" which includes the coin value.

The selection of metals used in the manufacture of alloys can be correlated with historical facts, technical details of manufacture, the provenance of the raw material, as well as the art and transformation of a society. According to the coin catalogs used as a reference in this work, the 21 coins analyzed were divided into four different types of alloys: 10 coins were made copper-nickel, 6 coins were made steel-nickel, 4 coins were made bronze and one coin was made brass. The only coin made of brass of this collection is that of Peruvian origin, minted in 1956 (A). On the other hand, the Bolivian coins in this collection have three different types of alloys. The coins made copper-nickel are the oldest coins in this collection, from 1876 to 1939 (B, F, K, N, O, P, Q, R, T and $\mathrm{U}$ ); the coins made of bronze are from 1942 to 1951 (C, J, M and S). In addition, the coins made of steel-nickel represent the most modern coins in this Bolivian collection, were minted from 1965 to 1980 (D, E, G, H, I and L). 


\subsection{XRF Analysis}

The coins were analyzed using the ARTAX 200 equipment. ARTAX 200 system (Bruker), consisting in an air-cooled that it has a Mo anode X-ray tube and an X Flash SDD detector (Silicon Drift Detector) with an energy resolution of $145 \mathrm{eV}$ for the $\mathrm{Mn}-\mathrm{K}_{\alpha}$ line energy. The XRF analysis were performed at six different points in each of the twenty-one coins, three on the heads and the other three on the tails, totaling 126 points. The analyses were performed with a voltage and current of $40 \mathrm{kV}$ and $600 \mu \mathrm{A}$, respectively, and an acquisition time of $100 \mathrm{~s}$. All the XRF-Spectra were evaluated using the open source PyMCA software package [9]. Figure 1 shows the experimental arrangement used in the ARTAX.

Figure 1: ARTAX with zoom of geometric set-up of the X-ray beam on the sample.

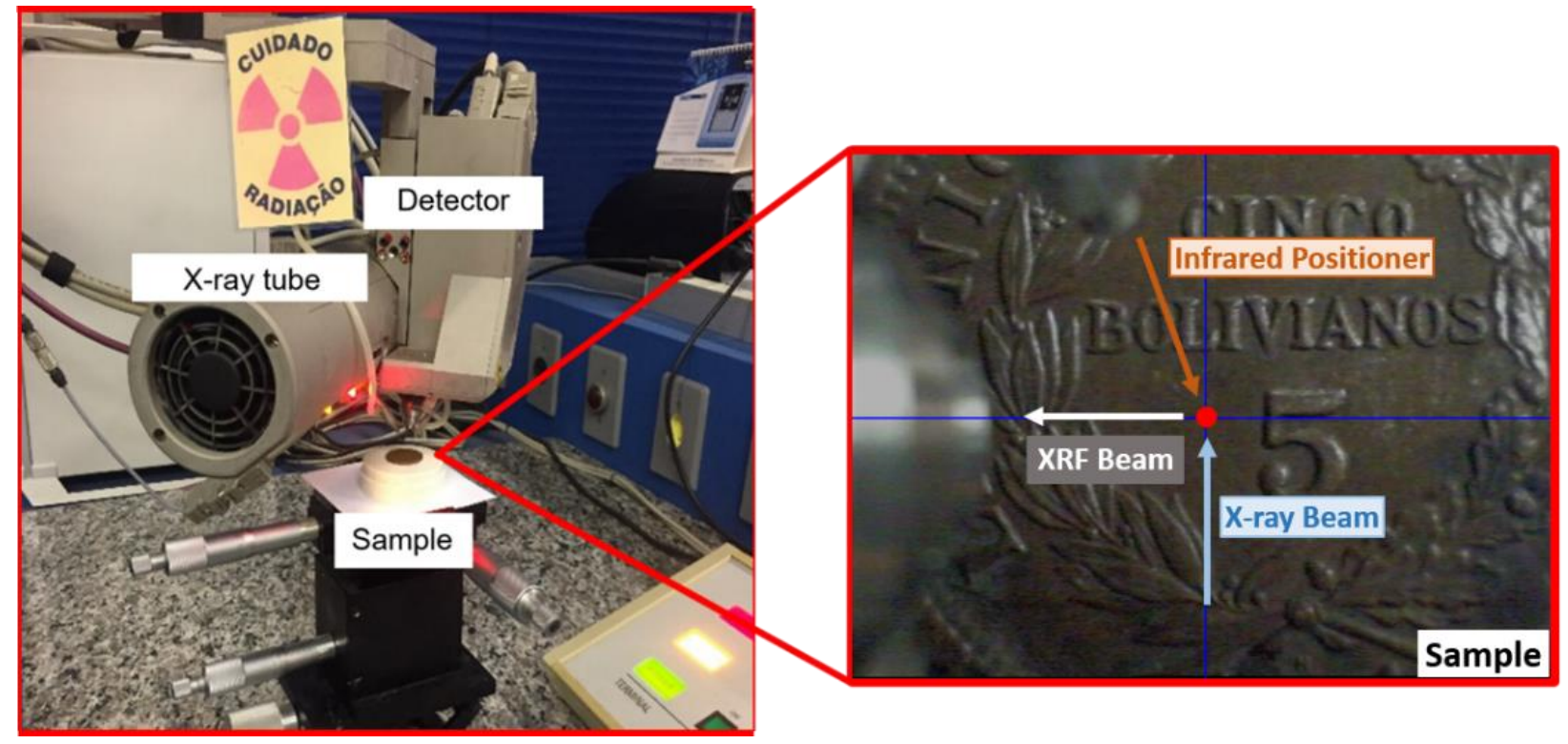


Table 1: Cataloged version and samples analyzed from A to $G$

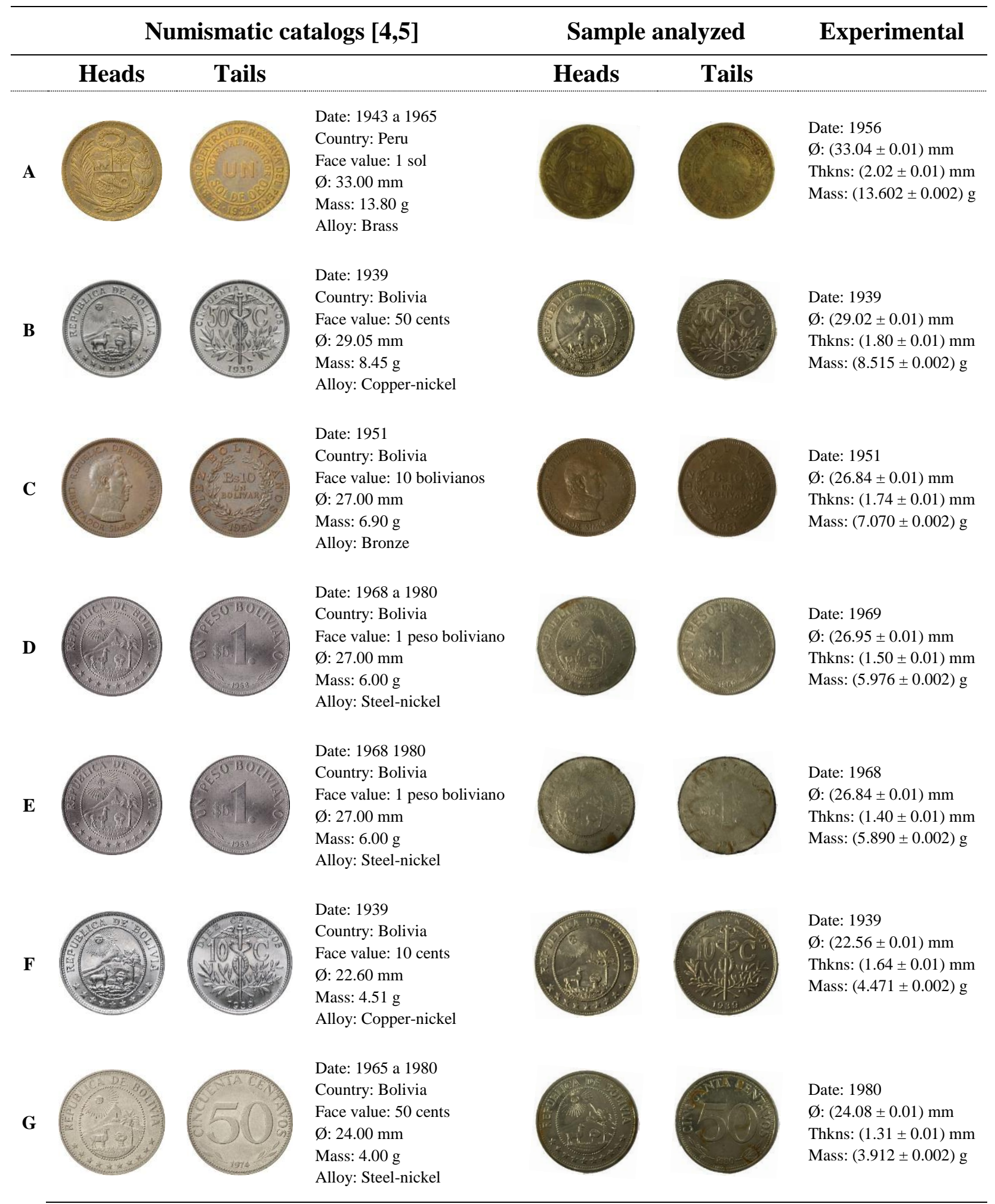


Table 2: Cataloged version and samples analyzed from $\mathrm{H}$ to $\mathrm{N}$

\begin{tabular}{|c|c|c|c|c|c|c|}
\hline \multicolumn{4}{|c|}{ Numismatic catalogs $[4,5]$} & \multicolumn{2}{|c|}{ Sample analyzed } & \multirow{2}{*}{ Experimental } \\
\hline & Heads & Tails & & Heads & Tails & \\
\hline $\mathbf{H}$ & & & $\begin{array}{l}\text { Date: } 1965 \text { a } 1980 \\
\text { Country: Bolivia } \\
\text { Face value: } 50 \text { cents } \\
\varnothing: 24.00 \mathrm{~mm} \\
\text { Mass: } 4.00 \mathrm{~g} \\
\text { Alloy: Steel-nickel }\end{array}$ & & & $\begin{array}{l}\text { Date: } 1965 \\
\text { Ø: }(23.99 \pm 0.01) \mathrm{mm} \\
\text { Thkns: }(1.21 \pm 0.01) \mathrm{mm} \\
\text { Mass: }(3.925 \pm 0.002) \mathrm{g}\end{array}$ \\
\hline $\mathbf{I}$ & & & $\begin{array}{l}\text { Date: } 1965 \text { a } 1980 \\
\text { Country: Bolivia } \\
\text { Face value: } 50 \text { cents } \\
\varnothing: 24.00 \mathrm{~mm} \\
\text { Mass: } 4.00 \mathrm{~g} \\
\text { Alloy: Steel-nickel }\end{array}$ & & & $\begin{array}{l}\text { Date: } 1974 \\
\varnothing:(23.97 \pm 0.01) \mathrm{mm} \\
\text { Thkns: }(1.24 \pm 0.01) \mathrm{mm} \\
\text { Mass: }(3.904 \pm 0.002) \mathrm{g}\end{array}$ \\
\hline $\mathbf{J}$ & & & $\begin{array}{l}\text { Date: } 1942 \\
\text { Country: Bolivia } \\
\text { Face value: } 50 \text { cents } \\
\emptyset: 24.60 \mathrm{~mm} \\
\text { Mass: } 5.10 \mathrm{~g} \\
\text { Alloy: Bronze }\end{array}$ & & & $\begin{array}{l}\text { Date: } 1942 \\
\text { Ø: }(24.50 \pm 0.01) \mathrm{mm} \\
\text { Thkns: }(1.54 \pm 0.01) \mathrm{mm} \\
\text { Mass: }(4.997 \pm 0.002) \mathrm{g}\end{array}$ \\
\hline $\mathbf{K}$ & & & $\begin{array}{l}\text { Date: } 1892 \\
\text { Country: Bolivia } \\
\text { Face value: } 10 \text { cents } \\
\varnothing: 25.00 \mathrm{~mm} \\
\text { Mass: } 4.70 \mathrm{~g} \\
\text { Alloy: Copper-nickel }\end{array}$ & & & $\begin{array}{l}\text { Date: } 1892 \\
\varnothing:(25.01 \pm 0.01) \mathrm{mm} \\
\text { Thkns: }(1.20 \pm 0.01) \mathrm{mm} \\
\text { Mass: }(4.706 \pm 0.002) \mathrm{g}\end{array}$ \\
\hline $\mathbf{L}$ & & & $\begin{array}{l}\text { Date: } 1965 \text { a } 1973 \\
\text { Country: Bolivia } \\
\text { Face value: } 20 \text { cents } \\
\varnothing: 22.00 \mathrm{~mm} \\
\text { Mass: } 3.20 \mathrm{~g} \\
\text { Alloy: Steel-nickel }\end{array}$ & & & $\begin{array}{l}\text { Date: } 1973 \\
\text { Ø: }(21.49 \pm 0.01) \mathrm{mm} \\
\text { Thkns: }(1.29 \pm 0.01) \mathrm{mm} \\
\text { Mass: }(3.019 \pm 0.002) \mathrm{g}\end{array}$ \\
\hline $\mathbf{M}$ & & & $\begin{array}{l}\text { Date: } 1951 \\
\text { Country: Bolivia } \\
\text { Face value: } 5 \text { bolivianos } \\
\varnothing: 23.00 \mathrm{~mm} \\
\text { Mass: } 5.00 \mathrm{~g} \\
\text { Alloy: Bronze }\end{array}$ & & & $\begin{array}{l}\text { Date: } 1951 \\
\varnothing:(23.02 \pm 0.01) \mathrm{mm} \\
\text { Thkns: }(1.69 \pm 0.01) \mathrm{mm} \\
\text { Mass: }(5.016 \pm 0.002) \mathrm{g}\end{array}$ \\
\hline $\mathbf{N}$ & & & $\begin{array}{l}\text { Date: } 1937 \\
\text { Country: Bolivia } \\
\text { Face value: } 10 \text { cents } \\
\varnothing: 22.50 \mathrm{~mm} \\
\text { Mass: } 4.50 \mathrm{~g} \\
\text { Alloy: Copper-nickel }\end{array}$ & & & $\begin{array}{l}\text { Date: } 1937 \\
\text { Ø: }(22.68 \pm 0.01) \mathrm{mm} \\
\text { Thkns: }(1.46 \pm 0.01) \mathrm{mm} \\
\text { Mass: }(4.551 \pm 0.002) \mathrm{g}\end{array}$ \\
\hline
\end{tabular}


Table 3: Cataloged version and samples analyzed from $\mathrm{O}$ to $\mathrm{U}$

\begin{tabular}{|c|c|c|c|c|c|c|}
\hline & \multicolumn{3}{|c|}{ Numismatic catalogs $[4,5]$} & \multicolumn{2}{|c|}{ Analyzed sample } & Experimental \\
\hline & Heads & Tails & & Heads & Tails & \\
\hline $\mathbf{O}$ & 0 & 0 & $\begin{array}{l}\text { Date: } 1883 \\
\text { Country: Bolivia } \\
\text { Face value: } 10 \text { cents } \\
\varnothing: 21.00 \mathrm{~mm} \\
\text { Mass: } 3.60 \mathrm{~g} \\
\text { Alloy: Copper-nickel }\end{array}$ & & & $\begin{array}{l}\text { Date: } 1883 \\
\emptyset:(21.00 \pm 0.01) \mathrm{mm} \\
\text { Thkns: }(1.27 \pm 0.01) \mathrm{mm} \\
\text { Mass: }(3.645 \pm 0.002) \mathrm{g}\end{array}$ \\
\hline $\mathbf{P}$ & & & $\begin{array}{l}\text { Date: } 1897 \text { a } 1909 \\
\text { Country: Bolivia } \\
\text { Face value: } 5 \text { cents } \\
\varnothing: 20.50 \mathrm{~mm} \\
\text { Mass: } 2.50 \mathrm{~g} \\
\text { Alloy: Copper-nickel }\end{array}$ & & & $\begin{array}{l}\text { Date: } 1909 \\
\varnothing:(20.07 \pm 0.01) \mathrm{mm} \\
\text { Thkns: }(1.38 \pm 0.01) \mathrm{mm} \\
\text { Mass: }(2.385 \pm 0.002) \mathrm{g}\end{array}$ \\
\hline $\mathbf{Q}$ & & & $\begin{array}{l}\text { Date: } 1892 \\
\text { Country: Bolivia } \\
\text { Face value: } 5 \text { cents } \\
\varnothing: 20.00 \mathrm{~mm} \\
\text { Mass: } 2.50 \mathrm{~g} \\
\text { Alloy: Copper-nickel }\end{array}$ & & & $\begin{array}{l}\text { Date: } 1892 \\
\varnothing:(20.46 \pm 0.01) \mathrm{mm} \\
\text { Thkns: }(1.27 \pm 0.01) \mathrm{mm} \\
\text { Mass: }(2.305 \pm 0.002) \mathrm{g}\end{array}$ \\
\hline $\mathbf{R}$ & & & $\begin{array}{l}\text { Date: } 1883 \\
\text { Country: Bolivia } \\
\text { Face value: } 5 \text { cents } \\
\varnothing: 17.80 \mathrm{~mm} \\
\text { Mass: } 2.40 \mathrm{~g} \\
\text { Alloy: Copper-nickel }\end{array}$ & & & $\begin{array}{l}\text { Date: } 1883 \\
\emptyset:(17.91 \pm 0.01) \mathrm{mm} \\
\text { Thkns: }(1.00 \pm 0.01) \mathrm{mm} \\
\text { Mass: }(2.116 \pm 0.002) \mathrm{g}\end{array}$ \\
\hline $\mathbf{S}$ & & & $\begin{array}{l}\text { Date: } 1951 \\
\text { Country: Bolivia } \\
\text { Face value: } 1 \text { boliviano } \\
\varnothing: 18.00 \mathrm{~mm} \\
\text { Mass: } 3.00 \mathrm{~g} \\
\text { Alloy: Bronze }\end{array}$ & & & $\begin{array}{l}\text { Date: } 1951 \\
\emptyset:(18.01 \pm 0.01) \mathrm{mm} \\
\text { Thkns: }(1.64 \pm 0.01) \mathrm{mm} \\
\text { Mass: }(2.982 \pm 0.002) \mathrm{g}\end{array}$ \\
\hline $\mathbf{T}$ & & & $\begin{array}{l}\text { Date: } 1883 \\
\text { Country: Bolivia } \\
\text { Face value: } 5 \text { cents } \\
\varnothing: 17.80 \mathrm{~mm} \\
\text { Mass: } 2.40 \mathrm{~g} \\
\text { Alloy: Copper-nickel }\end{array}$ & & & $\begin{array}{l}\text { Date: } 1883 \\
\varnothing:(17.78 \pm 0.01) \mathrm{mm} \\
\text { Thkns: }(1.07 \pm 0.01) \mathrm{mm} \\
\text { Mass: }(2.194 \pm 0.002) \mathrm{g}\end{array}$ \\
\hline $\mathbf{U}$ & & & $\begin{array}{l}\text { Date: } 1876 \\
\text { Country: Bolivia } \\
\text { Face value: } 5 \text { cents } \\
\text { Alloy: Copper-nickel }\end{array}$ & & & $\begin{array}{l}\emptyset:(16.21 \pm 0.01) \mathrm{mm} \\
\text { Thkns: }(1.30 \pm 0.01) \mathrm{mm} \\
\text { Mass: }(1.857 \pm 0.002) \mathrm{g}\end{array}$ \\
\hline
\end{tabular}




\section{RESULTS AND DISCUSSION}

Through the XRF spectra was possible to verify that all the coins were made by some type of alloy. Alloys are a combination of two or more different metals with the main intention of increasing the mechanical strength of the material, machinability, hardness, and other properties [10]. Figure 3 shows the XRF spectra for each of the four different types of alloys that compose the coins (brass, copper-nickel, bronze, and steel-nickel). The XRF spectra of the 21 samples of coins shown the presence of seven elements: $\mathrm{Mn}, \mathrm{Fe}, \mathrm{Co}, \mathrm{Ni}, \mathrm{Cu}, \mathrm{Zn}$ and $\mathrm{Sn}$.

Table 4 shows the intensities (number of photons detected per unit time) of the major elements found in each coin obtained from the PyMca program.

Figure 3: XRF spectra; a) coin A (brass), b) coin B (copper-nickel), c) coin D (steel-nickel), d) coin $S$ (bronze).

a)
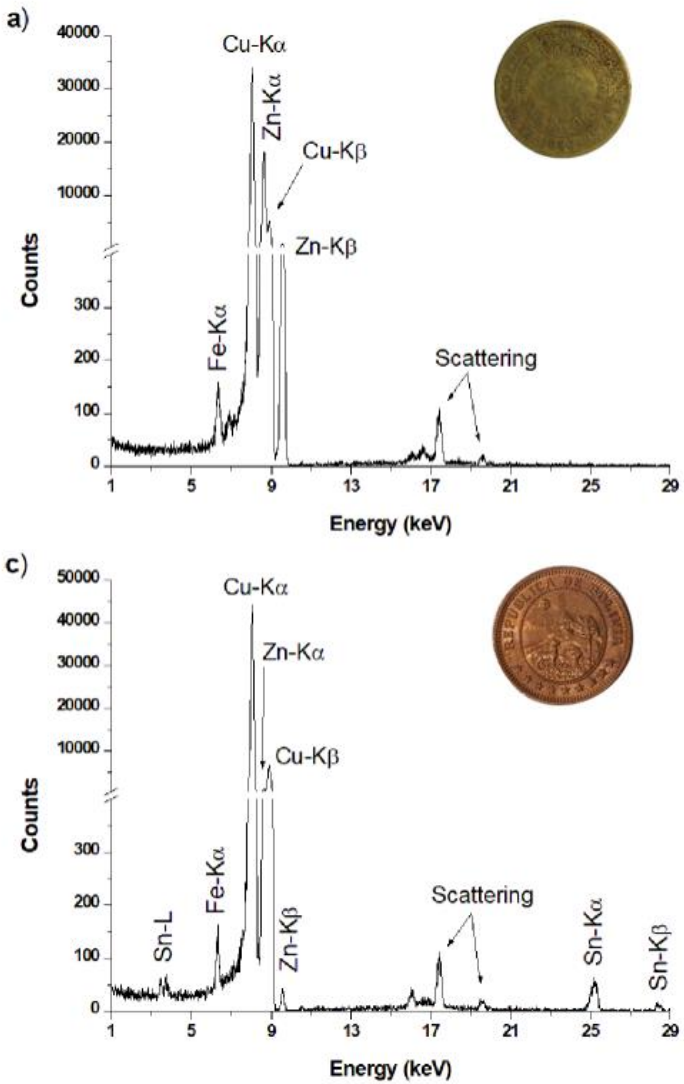

b)
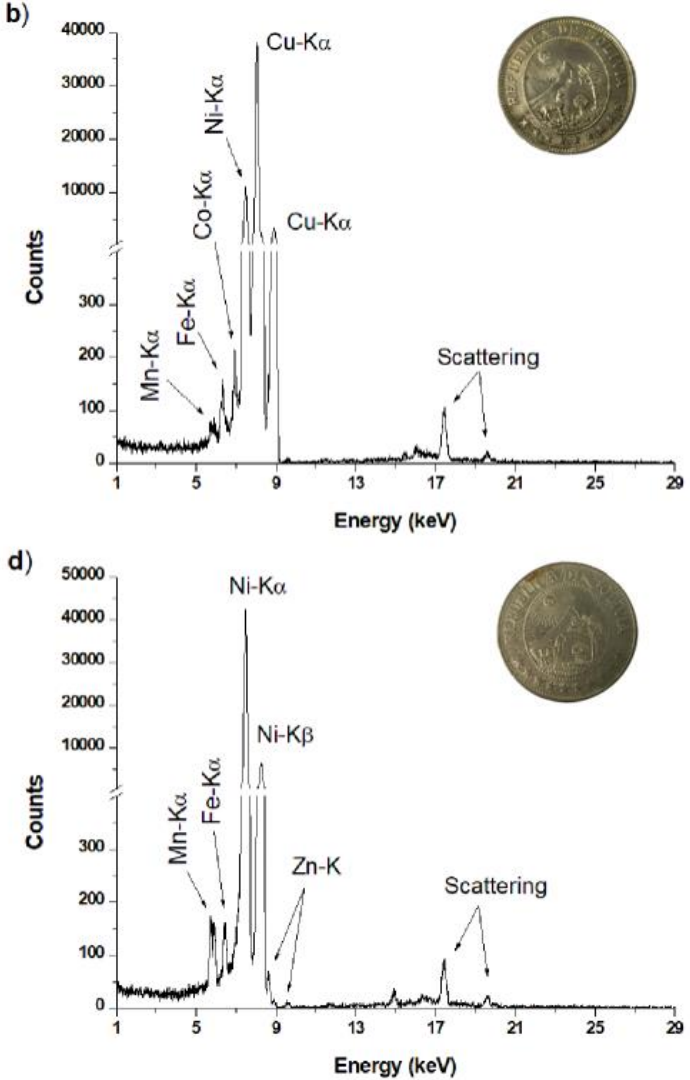
Table 4: XRF intensities of the main elements detected in the coins (Mean \pm Standard deviation, $n=6$ )

\begin{tabular}{|c|c|c|c|c|c|}
\hline \multirow{2}{*}{ Coin } & \multicolumn{5}{|c|}{ Main elements in the alloy ( mean \pm standard deviation) } \\
\hline & $\mathrm{Fe}$ & $\mathrm{Ni}$ & $\mathrm{Cu}$ & $\mathrm{Zn}$ & Sn \\
\hline A & $295 \pm 111$ & $\mathrm{ND}^{\mathrm{a})}$ & $476232 \pm 10603^{\text {b) }}$ & $243951 \pm 9168$ & ND \\
\hline B & $472 \pm 53$ & $146841 \pm 2470$ & $521176 \pm 7874$ & $1822 \pm 81$ & ND \\
\hline $\mathrm{C}$ & $273 \pm 46$ & ND & $599857 \pm 3886$ & $18540 \pm 203$ & $1711 \pm 38$ \\
\hline $\mathrm{D}$ & $1408 \pm 148$ & $567848 \pm 3234$ & $4584 \pm 300$ & ND & ND \\
\hline $\mathrm{E}$ & $1665 \pm 175$ & $566043 \pm 638$ & $3091 \pm 160$ & ND & ND \\
\hline $\mathrm{F}$ & $972 \pm 73$ & $149601 \pm 2716$ & $513889 \pm 6956$ & $1606 \pm 53$ & ND \\
\hline G & $1083 \pm 100$ & $567645 \pm 3832$ & $2614 \pm 73$ & ND & ND \\
\hline $\mathrm{H}$ & $1540 \pm 157$ & $573628 \pm 2706$ & $2769 \pm 482$ & ND & ND \\
\hline I & $2519 \pm 341$ & $563923 \pm 3856$ & $2908 \pm 175$ & ND & ND \\
\hline $\mathrm{J}$ & $2039 \pm 623$ & ND & $666793 \pm 5546$ & $10164 \pm 485$ & ND \\
\hline K & $3686 \pm 445$ & $143758 \pm 8225$ & $505138 \pm 14392$ & $1111 \pm 154$ & ND \\
\hline $\mathrm{L}$ & $1517 \pm 141$ & $568735 \pm 3361$ & $2922 \pm 98$ & ND & ND \\
\hline M & $656 \pm 107$ & ND & $605406 \pm 4010$ & $14073 \pm 298$ & $1717 \pm 81$ \\
\hline $\mathrm{N}$ & $554 \pm 46$ & $146419 \pm 1459$ & $505645 \pm 3079$ & $1209 \pm 80$ & ND \\
\hline $\mathrm{O}$ & $3321 \pm 342$ & $125985 \pm 11657$ & $494619 \pm 10985$ & $15739 \pm 920$ & ND \\
\hline $\mathrm{P}$ & $795 \pm 83$ & $145185 \pm 1305$ & $498078 \pm 5035$ & $1004 \pm 66$ & ND \\
\hline Q & $2644 \pm 360$ & $140249 \pm 5772$ & $503896 \pm 9307$ & $1051 \pm 58$ & ND \\
\hline $\mathrm{R}$ & $1743 \pm 91$ & $128027 \pm 2176$ & $511738 \pm 4999$ & $8740 \pm 262$ & ND \\
\hline$S$ & $309 \pm 94$ & ND & $578481 \pm 38247$ & $13669 \pm 1162$ & $1729 \pm 153$ \\
\hline $\mathrm{T}$ & $2119 \pm 201$ & $130245 \pm 5146$ & $489594 \pm 21357$ & $8339 \pm 300$ & ND \\
\hline $\mathrm{U}$ & $4112 \pm 125$ & $79790 \pm 1087$ & $455191 \pm 9281$ & $102208 \pm 7080$ & ND \\
\hline
\end{tabular}

a) $\mathrm{ND}=$ Element not detected.

b) Counts in bold = Major elements in the alloy. 
The coin A (Figure 3a) is the only Peruvian coin in the study. This is the "Sol de Oro" coin, minted in 1956. According to Ortega-San-Martín et. al. [8] the one and two-cent coins of Sol de Oro were minted in Peru between 1950 and 1956 and removed from circulation after this period due to two global economic crises that strongly affected international zinc and copper prices. Besides that, according to the authors, the only period in which the Lima Mint (Casa Nacional de la Moneda, Peru) produced zinc coins was between 1931 and 1985. In the XRF spectrum of the coin A (Figure 3a) was detected three elements: $\mathrm{Fe}, \mathrm{Cu}$ and $\mathrm{Zn}$, where $\mathrm{Cu}$ and $\mathrm{Zn}$ showed higher intensities (Table 4). Brass is an alloy made up of copper and zinc, with a different combination, this alloy can be varied properties. Therefore, the results obtained by XRF indicate that this coin is made of brass. For comparison, in the coin catalogs $[4,5]$, this alloy is composed of $60-70 \%$ copper and $40-30 \%$ zinc, which is following the result obtained.

Copper-nickel is an alloy made up of copper and nickel and it is common for this alloy to have a silver-gray coloration [10, 11]. Ten coins in this collection were made of copper-nickel; they are $\mathrm{B}$, F, K, N, O, P, Q, R, T and U. All of the Bolivian origin. Five of five-cent face value (P, Q, R, T and $\mathrm{U})$, four of ten-cent face value (F, K, N and $\mathrm{O}$ ) and one of fifty-cent face value (B). The oldest coin in the analyzed collection is dated 1876 (coin $\mathrm{U}$ ) was made from this alloy. Figure $3 \mathrm{~b}$ shows the XRF spectrum of the coin $\mathrm{B}$, where five elements were detected: $\mathrm{Mn}, \mathrm{Fe}, \mathrm{Co}, \mathrm{Ni}$ and $\mathrm{Cu}$. The elements $\mathrm{Ni}$ and $\mathrm{Cu}$ presented higher intensities (Table 4). Although the main elements of the alloy being copper and nickel, it was possible to verify that the presence of the other elements mixed in the alloy varied considerably from one minting to the other. In the coin $U$, minted in 1876 , it is possible to note (Table 4) that the intensity of iron and zinc is higher than in the coin P (same face value and alloy), minted in 1909. Moreover, the presence of the main elements of the alloy, copper, and nickel, have greater intensity in the $\mathrm{P}$ coin. Changes in the size and metallic composition over the 33 years that this coin continued in circulation may have been motivated by changes in the economy and technological advancement in the process of alloy manufacture. The coin catalogs [4, 5 ] indicate that these coins have about $75 \%$ copper and $25 \%$ nickel, which is in agreement with the results obtained in this study, indicating that these 10 coins can be made of a copper-nickel.

The coin D spectrum represents the steel-nickel (Figure 3c). In this XRF spectrum were detected three elements: $\mathrm{Mn}, \mathrm{Fe}$ and Ni, where Fe and Ni presented higher intensities (Table 4). Steel-nickel is an alloy made up of iron, carbon, and nickel. The word "steel" can be defined as 
carbon in iron, in addition to residual elements [12]. Six of the twenty-one coins were made with steel nickel alloy (D, E, G, H, I and L). These six coins are Bolivian, and they are the most recent in the collection, minted between 1965 and 1980. One coin with a face value of twenty-cents (L) minted in 1973, three coins with the face value of fifty-cents (H, I and G), minted between 1965 and 1980 and two coins with the face value of 1 Bolivian peso (D and E), minted in 1968 and 1969. According to the literature, they are all nickel clad steel $[4,5]$.

Bronze is represented in this study by coins C, J, M e S. Figure 3d shows the XRF spectrum of the coin $\mathrm{S}$ (bronze) and four elements were detected: $\mathrm{Fe}, \mathrm{Cu}, \mathrm{Zn}$ and $\mathrm{Sn}$, where $\mathrm{Cu}, \mathrm{Zn}$ and $\mathrm{Sn}$ presented highest intensities (Table 4). By combining copper with other metals, it is possible to obtain many copper alloys with different properties and colors through chemical or electrochemical processing of their surfaces. Its metallic tones vary from red to yellow to silver-gray. That is, the color of the coins is related to the combination of the elements used in the production of the alloy $[11,12]$.

Bronze is a range of alloys in which the principal elements are copper and tin, with about approximately $90-70 \%$ copper and $10-30 \%$ tin. According to the purpose, variable proportions of other elements such as zinc, aluminum, antimony, nickel, phosphorus, lead, among others, can be added to obtain different properties [11]. The results obtained in this study are consistent with the results presented in the catalog [4,5]; however, an alloy with $\mathrm{Cu}, \mathrm{Zn}$ and $\mathrm{Sn}$ as main elements can also be found in the literature as Tin brass. Tin brasses are alloys made from copper, zinc ( $2 \%$ to $40 \%)$ and tin $(0.2 \%$ to $3 \%)$ [10].

Twenty coins were consistent with their cataloged version $[4,5]$. On the other hand, only one coin (coin J) showed a different chemical composition from its cataloged version. Figure 4 shows the XRF spectrum of coin $\mathrm{J}$.

According to the catalogs, coin $\mathrm{J}$ should be a bronze (90-70 \% Cu, 10-30 \% Sn). However, the XRF analysis showed that the main elements used in the minting of the coin $\mathrm{J}$ were $\mathrm{Cu}$ and $\mathrm{Zn}$, which are the principal elements of brass. The tin element was not detected in this coin.

Brasses have a range of colors, ranging from red to yellow to gold to silver, depending on the amount of zinc the alloy contains [12]. The combination used in mintage of coin A resulted in a pale yellow, while for coin $\mathrm{J}$ (Figure 4), the result obtained was reddish-brown. Both coins have 
been made of brass; however, the proportion of the elemental composition is different between them.

Although the color and size are similar to those of the cataloged coin, this result raises the hypothesis that this coin should be a replica of the original coin, minted in 1942.

Figure 4: XRF spectrum of the coin $J$

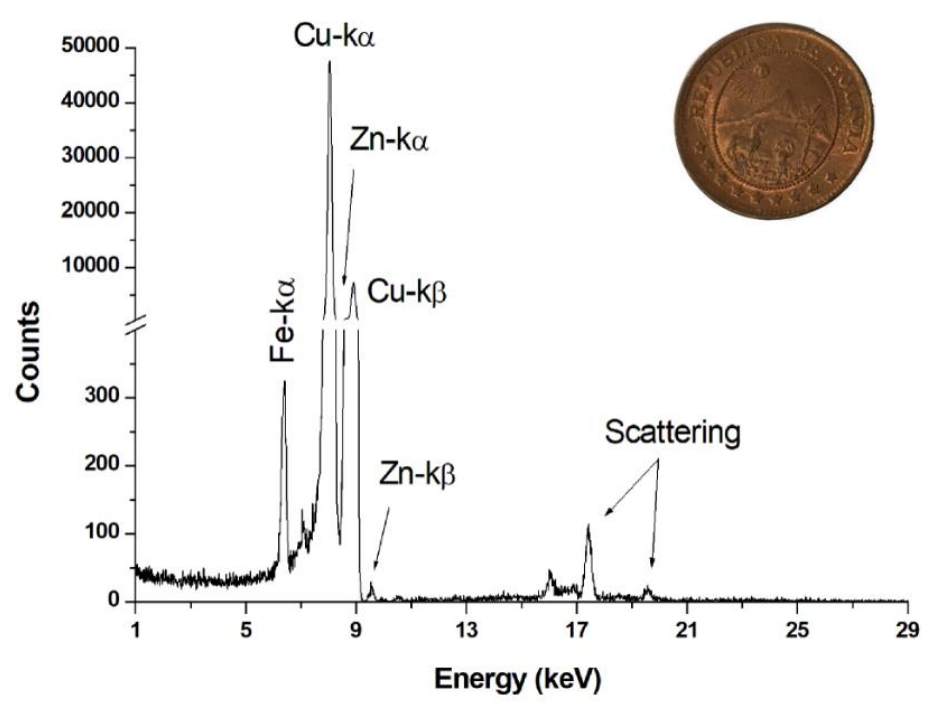

\section{CONCLUSION}

Through the analysis of XRF of the 21 coins, it was possible to evaluate that all 21 coins were made of alloys formed from the combination of the elements $\mathrm{Fe}, \mathrm{Cu}, \mathrm{Ni}, \mathrm{Zn}$ and $\mathrm{Sn}$. The coins were classified according to the elemental compositions of each alloy found in the literature. The main elements used in the minting of coin A were copper and zinc, i.e., characteristic of the brass. The copper-nickel, whose main elements are $\mathrm{Cu}$ and $\mathrm{Ni}$; it was detected in ten coins $(\mathrm{B}, \mathrm{F}, \mathrm{K}, \mathrm{N}, \mathrm{O}, \mathrm{P}$, $\mathrm{Q}, \mathrm{R}, \mathrm{T}$ and $\mathrm{U})$. The bronze $(\mathrm{Cu}+\mathrm{Sn})$ was detected in three coins $(\mathrm{C}, \mathrm{M}$ and $\mathrm{S})$ and the Steel-nickel was detected in six of the twenty-one coins (D, E, G, H, I and L). However, the main elements presented in the coin $\mathrm{J}$ composition were $\mathrm{Cu}$ and $\mathrm{Zn}$. Therefore, the coin $\mathrm{J}$ did not present the elemental composition expected when compared to its cataloged version, bronze, which may be an 
indication that this coin may be a fake. The results obtained in this work confirm that the analysis by $\mathrm{XRF}$ is an efficient method to characterize and helping to authenticate artifact of historical interest. 


\section{ACKNOWLEDGMENT}

This study was financed in part by the Conselho Nacional de Desenvolvimento Científico e Tecnológico $(\mathrm{CNPq})$, the Fundação Carlos Chagas Filho de Amparo à Pesquisa do Estado do Rio de Janeiro (FAPERJ) and Coordenação de Aperfeiçoamento de Pessoal de Nível Superior - Brazil (CAPES) - finance code 001 and Financiadora de Estudos e Projetos (FINEP - CT-INFRA 01.13.0444.02).

\section{REFERENCES}

[1] PITARCH, A., QUERALT, I., Energy dispersive X-ray fluorescence analysis of ancient coins: the case Greek silver drachmae from the Emporion site in Spain, Nuclear Instruments and Methods in Physics Research Section B, v. 268, pp.1682-1685, 2010.

[2] M.VAdRUCCI. MAZZINGHI, A., GORGHINIAN, A., PICARDi, L., RONSIVAlle, C., RUBERTO, C., CHIARI, M., Analysis of Roman Imperial coins by combined PIXE, HE-PIXE and $\mu$-XRF, Applied Radiation and Isotopes, v. 143, p. 35-40, 2019.

[3] NAVAS, M. J., ASUERO, A. G., JIMÉNEZ, A. M., A Review of Energy Dispersive X-Ray Fluorescence (EDXRF) as an Analytical Tool in Numismatic Studies, Applied Spectroscopy, v. 70, p. 207-221, 2016.

[4] COLNECT. Coin catalog. Spain. Available at: <https://colnect.com/es/coins/countries>. Last accessed: 10 May. 2019.

[5] COINS AND CURRENCY. South America gallery. Available at:

<http://www.coins.calkinsc.com/southamerica_gallery.html $>$. Last accessed: 12 May. 2019.

[6] CORSI, J., LO GIUDICE, A., RE, A., AGOSTINO, A., BARELlO, F., Potentialities of X-ray fluorescence analysis in numismatics: the case study of pre-Roman coins from Cisalpine Gaul, Archaeological and Anthropological Sciences, v. 10, p. 431-438, 2018.

[7] GORGHINIAN, A., ESPOSITO, A., FERRETTI, M., CATALLI, F., XRF analysis of Roman Imperial coins, Nuclear Instruments and Methods in Physics Research Section B, v. 309, p. 268-271, 2013. 
[8] ORTEGA-SAN-MARTÍN, L., SARANGO-RAMÍREZ, M. K., GALARRETA, B. C., Modern coin debasement discovered by combined portable X-ray fluorescence and atomic absorption spectroscopy in Peruvian cent coins (1950-1965), X-ray Spectrometry, v. 48, p. 21-28, 2019.

[9] SOLÉ, V.A., PAPILLON, E., COTTE, M., WALTER, P., SUSINI, J., A multiplatform code for the analysis of energy-dispersive X-ray fluorescence spectra, Spectrochimica Acta Part B: Atomic Spectroscopy, v. 62, p. 63-68, 2007.

[10] CDA: Copper Development Association. The cooper advantage: A guide to working with copper and copper alloys, United State of America, 2010, p.28.

[11] GARDAM, G. E., The colours of some metals and alloys, The International Journal of Surface Engineering and Coating, v.1, 186-188, 2017.

[12] CDA: Copper Development Association. Brasses: Properties applications. United State of America. Available at: <https://copperalliance.org.uk/knowledge-base/resource-library/brassesproperties-applications/>. Last accessed: 13 Dec. 2019. 